\title{
How to Increase primary Students' Enthusiasm for Learning English?
}

\author{
Zhiyong Sun \\ Chifeng University 024000
}

\begin{abstract}
Society is making progress, science and technology is developing. Nowadays the development of learning ability is required in the quality education. English is an important discipline of primary school, while the primary school stage is a very important period to cultivate a habit which will determine a person's lifelong development. How to make primary school English language teaching from boring lectures and rotting learning model? Only to create an atmosphere of democracy, a harmonious teacher-student relationship, relaxed environment, opened space and creative passion, can students in positive atmosphere to learn English well. In the following I want to talk about some of $\mathrm{my}$ own thinking about how to enhance primary students' enthusiasm for English learning.
\end{abstract}

\section{Key words- learning, english, enthusiasm, primary}

\section{The necessity of improving students' enthusiasm}

English is primary and middle schools important stage discipline, and the primary school stage is the important time for every young student, it will decide human's lifelong development foundation. By the way, to some extent that enthusiasm equals interest. If a boy or a girl who loses the interest for study, it would be bad to his or her the basic study. And whatever learns a kind of language, skill and so on, I deem that personal interesting is the best teacher for learning. So at this point build up the students enthusiasm is helped from the students' personal interest. In addition, primary student has not wanted to play all the time. Therefore must pay attention to guide them in the study, mainly is let children find the interest on study. By this kind of way that advocate the enthusiasm of initiative of them, can they search study pleasure. As parents or teacher that we must let them know the importance of learning in the playing, and inspire them find the suitable way to think. From the other side that the interest is a person makes every effort the contact, the understanding, grasps some kind of thing and participates in some kind of active the psychological tendency. For instance, an elementary student likes the mathematics course specially, makes the mathematics problems, participates in mathematics competition positively, we said this student has had the interest to mathematics. The interest is in the foundation which needs, produces in the social activity with the development. The interest is the elementary student studies in the enthusiasm one most positive, the most active psychological factor. If the elementary student has the interest to study that could improve own initiative, positive on own initiative carry on the study and the exploration. Nowadays, study to them should be one kind of pleasure, but was not one kind of pain that certainly helpful in them obtains the good result. Has raises his study interest, can raise his learning capability. Only then had the learning capability, can learn the knowledge and the skill. Had the knowledge and the skill, can stimulate the study the enthusiasm. 


\section{Some factors effecting the development of enthusiasm}

Why is the development of enthusiasm stopped? Now I will try to find the reasons.

\section{A. Students}

\section{Passive form study}

Most form of teaching always puts big pile schoolwork to every student, but forgets to include students to learning from their own habit. As students can they do just waiting for the knowledge what they need, and they needn't to search the contraction or the background knowledge. So some students lose the chance to improve the necessity of adding knowledge, then they couldn't have enough enthusiasm for learning. Because of passive form of leaning that more and more students change their altitude of study to wait for attaining the knowledge. According to the survey that above $90 \%$ students to be likely same on the desert in camel in Chinese now, it does not want to walk forward, it is being hit by the hunchbacked person and entrains is walking forward.

\section{Tasteless transcribing}

According to my personal experience say, the majority class in English all are carrying on repeatedly transcribing, certainly I do not deny transcribe have many help regarding English study, but to the elementary student, the relapse transcribes can some have the reverse side function. For instance, different teachers have the different teaching method, possibly have some teachers to be able to let the student make the massive word transcription of work, and the student just likes the machine for massive working, then this kind of memory way cannot let student to use their brains and the hearts go to the memory and studies.

3. Does not pay enough attention in English

The language class and the mathematics course occupy the study time is so long, many children only regard English study as a vice-class and has not given the essential value. In some economical backward area, the education level which each guardian accepts is in particular dissimilar, the most guardians thought that their children so long as have learned mathematics and the language has been good, this kind of thought also caused some elementary students not to take regarding English, so that has lost the study interest and the enthusiasm gradually.

\section{B. Teachers}

Teacher acts in the classroom study is very important to help dispelling with the doubt what the students have, is the key to student studies the necessary lessons, therefore we should from the angle of teaching to discusses the effects about the student enthusiastic question.

1. The classroom form is too stodgy

Although the modern teaching method is providing continuously, for example uses the multimedia teaching, but many teachers when on class in English chooses the sole teaching form to the children actually. According to the investigation, at the same time $70 \%$ school English teacher is having several class's and grade's lessons who does not have excessively more energy to pay attention to the teaching form, even also has many teachers only has a sample look about textbook and to attend class, has very few glances through the material, ponder more profits in the teaching question now. Also only when the higher authority attends to lessons, teachers can with all mental efforts use each teaching method to guide the children to study. But is usually short interacts with children, like plays the game, makes the competition and so on. 2. Takes the grammar practice excessively

Many English teachers complained that the elementary school English is more and more difficult to teach, and the student also more and more difficult to learn. The question is the present examination paper is more and more difficult, some paper pays great attention to the grammar knowledge, the practice also is so hard and strange. In order to enhance student's test result, the teacher when attends class often spends more 
time in the explanation grammar .The massive practice time has occupied listening time and speaking time, let the most elementary students to lose the English study interest, so how to enhance the children' enthusiasm?

3 . Is compelled to achieve the teaching goal

Along with enters higher school, the pressure progressive is reducing to next graduate, the teaching pressure is also pressing the general teachers, so teachers have to throw the pressure to every elementary student. However the study form no longer is learns through playing, but also is in order to obtain several proportions of students entering schools of a higher grade. Because of this solution, most teachers could not take their attention to enhance the enthusiasm for English. This kind of completing the teaching duty which is said that it's a failure, because it abandon basic study of language, abandon the joy, and also abandon the true needed thing of children.

\section{Effective ways to improve enthusiasm}

\section{A. Students \\ 1.Change the passive form of study to initiative study}

In the current advancement education for development situation, transforms student's study way to appear importantly. The following are my ideas. Firstly, let students know the aim to study. English just like a key to open the world's window, only can we learn it well so that can we do enhance the relation with the other citizen on the earth. Secondly, prepared for class and find the appropriate relevant knowledge. As elementary students, we couldn't ask them to make fully preparation for English lesson, but we could let them to preview the textbook and know the content of teaching. What's more, parents can help their children to build up the good habit of learning, such as draw up a study plan and find their own way to study.
2. Changes in attitude will become unnecessary transcribe to effective memory

Most elementary students just act transcribe as a burden of learning, even hate this kind of schoolwork. However, if students can use to improve own copy of the reserve word or simple sentence parodies, that the purpose of education is attained. As the saying goes, write through own hands is better than scan through own eyes, if kids use their heads and hearts that they are very easy to learn the knowledge. Because of this , should build up a learning attitude that" I want to learn ,I want to remember", and effectively improve their vocabulary and ability to use sample sentences.

\section{Pay necessary attention to learn English}

In my opinion, learning English and learning our mother tongue should be unified. Because as a kind of language, they should learn from each other, so should spend more time to learn it. First of all, should pay attention to it in terms of ideology. In some economies less developed areas, teachers should communicate with parents and tell them a country's development is inseparable from the world, and if we want to understand this world that we must use English. In addition, primary school is the golden age of language learning, but also paving the way in the future for their children.

\section{B. From the help of teachers}

\section{Create active classroom atmosphere}

Firstly, use the game, performance, competition, English songs and practice of various activities, put learning and playing organically. Gradually transfer the knowledge to students, arouse their interest and enthusiasm. For example, compile the English words into nursery rhyme or review the words about sports, teachers to do action, students guess. But do not blindly pursue the classroom to the diverse forms of corruption more than demand perfection, but has become an excuse for children to play. In short, we should let students to play on study and study in the play, but to pay attention to the scale. 
2. Grasp grammar teaching principle and take advantage of situational teaching

Although English Curriculum book also pointed should dilute grammar teaching, but it does not mean that not to learn English grammar. When face heavy English grammar exercises, mangy teachers had to put amount of grammar into usual teaching. To me, I deem that should try to use the following ways. In the first place, when explain grammar item, teachers should pay attention to proper principles, equal to explain it timely, appropriate, to explain it clearly to be understood, otherwise it could result in a child confused and annoyed. Secondly, psychological research shows that if students heard and saw the language which appeared in the dialogue among the structure of sentence and grammar, they will speak fluently through their mouths. This way of teaching will be more intuitive, interesting, lively, and will not allow students to feel dull and mechanical. For instance, take students to playground of school, and then the teacher could tell her or his students "I can play basketball, I'm playing basketball" with patting the basketball on the hand. And you can ask them "who can play basketball?", so it must have some students to repeat your words. Then, the teacher wrote on the blackboard: I'm basketball, let students practice and answer with each other, while could also correct their mistakes and reach the desired result.

3. Equip with more professional English teachers to improve the teaching situation

According to the survey, $80 \%$ of primary teachers are not systematically studied linguistics, teaching methods, child psychology and pedagogy. In addition, $40 \%$ of teachers do not read magazine, lack the knowledge of English country's history and geography, customs, and cultural traditions. Therefore, we should absorb those who graduated from Normal University English major, have the good quality, interested in primary school English teaching young talent into the primary school, besides can also encourage to recruit non-English major graduates or graduate from Teachers College in Non English to teach in primary schools. This way of recruiting must decrease the heavy burden of the primary school teachers and also inject the flesh blood to teaching staff. In addition, every primary school should consider own situation, make a reasonable planning for equating primary teachers, working capacity on the primary school English teaching. Besides, allow the teachers have enough time to research students, teaching materials and methods to stimulate students to learn English.

\section{Conclusion}

Interest is the best teacher, we should create an atmosphere of learning English, start from the interest of students, and use the psychological characteristics of this age, learn to remove students' enthusiasm. Through play games, make performances, sing and so on to advocate students' participation, cooperation and exchanges, enhance the ability of using language so that all the students are full of vitality in the classroom. All in all, in the age of primary school, we should try our best to let every student attain the basic knowledge and arouse their enthusiasm for learning English. These are my proposals.

\section{Reference}

[1] Xuqiang. Communicative English Teaching and Assessment of Testing. Shanghai Foreign Language Education Press. 2000.

[2] Zhao Guoqiang. Discussion on English Teaching. Foreign Language Teaching. 2000,1. 